\title{
Balancing Work and Caregiving: A Guide for Employers ${ }^{1}$
}

Carolyn S. Wilken ${ }^{2}$

Providing care for older family members has become a way of life for millions of Americans. In fact, nearly one in ten American workers is a caregiver. By 2007, 15.6 million Americans will be trying to balance working and caregiving responsibilities. Seventy percent of employers feel that caregiving-related staffing problems have increased over the past ten years, and 92\% believe these problems will increase over the next ten years.

\section{Caregiving Costs Businesses}

U.S. businesses are highly impacted by caregiving. A 2004 National Alliance of Caregiving/AARP study funded by MetLife estimated that each year, businesses suffer a \$29 billion loss in productivity due to caregiving. That equals approximately $\$ 1,142.50$ per employee. Employers who are also caregivers account for nearly $75 \%$ of early departures and late arrivals at the workplace. Caregivers often make long telephone calls while at work to handle caregiving issues. Working caregivers have more stressrelated illnesses. They use the company's health care plan more and add additional cost for the employer.

Employees who find the competing demands of work and caregiving to be too much may have to leave their jobs. They face a serious financial and emotional toll. MetLife/AARP estimated that over a lifetime, the average caregiver forgoes nearly \$700,000 in "wage wealth." Wage wealth includes lost wages, lost Social Security income, and lost pension benefits. Caregivers who enjoy their jobs and who are friends with their coworkers may also become depressed and lonely after quitting.

\section{What Can Employers Do?}

Providing in-house support for caregivers may help keep employees on the job longer. This will help reduce the stresses on the employee, his or her co-workers, and you, the employer.

\section{Family Medical Leave Act (FMLA)}

As an employer, you may be required by law to abide by the Family Medical Leave Act. Although this law was written to provide families with secure employment during times of family crisis, it can be seen by employers as expensive and disruptive, especially when abused.

While some employees take FMLA for the birth or adoption of a child, those who take leave to be full-time caregivers are not leaving for happy times. Most would prefer working to providing care for a critically ill or dying family member.

1. This document is FCS2261, one of a series of the Department of Family, Youth and Community Sciences, Florida Cooperative Extension Service, IFAS, University of Florida, Gainesville FL 32611. First published: November 2006. Please visit the EDIS Web site at http://edis.ifas.ufl.edu.

2. Carolyn S. Wilken, PhD, M.P.H., associate professor, Department of Family, Youth and Community Sciences, Florida Cooperative Extension Service, IFAS, University of Florida, Gainesville FL 32611. Appreciation is given to Katherine Allen, CED, Citrus County Extension/University of Florida and Jennifer A. Wells, Regional Extension Agent/Auburn University, for suggestions and comments. 


\section{Tips Regarding FMLA}

- Know your responsibilities as an employer.

- Respect your employees’ rights under FMLA.

- Offer solutions such as flexible work hours, telecommuting, or job-sharing. This way, you may actually avoid the need for FMLA.

\section{Develop an In-House Support Program for Caregivers}

Human resource departments routinely deal with personal issues of employees. They handle such concerns as drug and alcohol abuse, domestic violence, absenteeism, and financial concerns. Yet most do not provide specific support for caregivers of elderly or disabled family members. Employees may come to you with other problems, but after a closer look, the human resource specialist may learn that the problems are related to caregiving. Is your human resource department ready to help employees with caregiving concerns?

The following six steps provide a very simple outline of a program to support family caregivers:

- Assess employee needs for caregiving support.

- Identify a key HR staffer to specialize in caregiving.

- Develop a caregiving support campaign.

- Provide follow-up.

- Assess results of program.

Assess employee needs in two ways: First, find out how many employees are currently providing caregiving. Then screen for caregiving issues when employees are referred or self-refer to human resources. Caregiving often becomes such a routine part of the employee's life that they do not see it as a concern.

Provide specific training in gerontology and aging issues for the HR staffer. If your company is large, you may need someone to specialize fulltime in caregiving and aging issues. Hire a gerontologist (aging specialist) who knows the aging network. She or he can develop strategies that will help the employee balance work and caregiving.
Campaign using your company's established communication tools. Let your employees know that you are aware of the realities of caregiving and have services available to support them. Avoid one-shot informational programs. Ask HR staffers to conduct routine follow-up evaluations throughout the caregiving period and beyond.

Assess the results of your program to see what difference it made in the lives of your employees and in your company's productivity. Get

suggestions from current employee caregivers to help improve the program for others.

\section{Informal Support Systems for Smaller Business and Offices}

If you do not have a formal Human

Resources department, talk to your employees about caregiving. Keep the focus on communication. Offer tips for setting limits and boundaries that can help caregivers gain control over their situation.

Your involvement may give the caregivers the impetus they need to be more vocal with family members about the conflicts they feel between work and caregiving. For instance, a caregiver might find it useful to tell their care receiver, "My employer said that I can only make one personal phone call in the morning and one in the afternoon. I'll call you when I get a break." Or he or she might say to a sibling, "You'll have to take mom to her appointments part of the time, because I cannot be gone from the office so much.”

\section{Final Recommendations}

Talk openly with your employees. Let them know that you value them as employees and as people. Tell them that you want to do whatever you can to keep good employees. Let them know about the resources you can offer. In an open and honest discussion, explain what temporary adjustments you can make in the work setting and what adjustments or accommodations you cannot make.

Encourage employees to ask for help. If your company has an HR department that is prepared to deal with such issues, of course you will refer them to HR. On the other hand, if you do not have 
an HR department, suggest they start by calling 21-1. 2-1-1 is an information and referral network developed and sponsored nationally by the United Way and available in larger cities and counties. Or they can start by calling Eldercare Locator at 1800-677-1116. Eldercare Locator will put caregivers in touch with their local Area Agency on Aging information and referral specialists. It is a public service provided by the United States

Administration on Aging. Information can also be found at their Web site: http://www.eldercare.gov.

\section{References}

Caregiving in the U.S. (2004). National Alliance for Caregiving/AARP. Retrieved July 17, 2005, from http://www.caregiving.org/data/04finalreport.pdf

Older Americans 2000: Key Indicators of Well-Being. (2000.) Federal Interagency Forum on Aging-related Statistics. Retrieved July 17, 2005, from http://agingstats.gov

Employed Caregivers. (2003). US Department of Health and Human Services, Administration on Aging, Washington DC. Retrieved October 30, 2006, from http://www.aoa.gov/press/nfc_month/2003/nfcm_factsheets/3\%20employed\%20caregivers.pdf

This is one of six publications in a series on caregiving and aging. The other publications in this series are:

Long-Term Care: Places to Call Home (http://edis.ifas.ufl.edu/FY869)

Caregiver’s Contacts: How to Get the Help You Need (http://edis.ifas.ufl.edu/FY870)

When Your Care Receiver Refuses Help: Questions to Ask (http://edis.ifas.ufl.edu/FY871)

Balancing Work and Caregiving: Tips for Employees (http://edis.ifas.ufl.edu/FY872)

Final Wishes: End-of-Life Decisions (http://edis.ifas.ufl.edu/FY874) 